at Brown and Columbia Universities, which received support from Government and industry. In addition to providing instruction in the necessary techniques, it will be necessary to indicate the existence of unsolved problems in industry which can lead to interesting mathematical developments. While it is hoped that those mathematicians who have been engeged on engineering problems during the War, having realized the unsuitability of their university training for such work, will, on their return to academic life, adapt the courses accordingly, this will not deal with the whole problem. Since the principle of the sabbatical year has not been accepted in the new Scientific Civil Service and in view of concentration of industrial research associations within reach of London, it would appear desirable and opportune for the University of London to provide suitable postgraduate courses.

\section{THE EGYPTIAN ACADEMY OF SCIENCES}

\section{By A. M. MOSHARRAFA PASHA}

Dean of the Faculty of Sciences, Fouad I University, Cairo

$\mathrm{E}^{\mathrm{a}}$ GYPTIAN men of science have for some time felt the need for establishing an academy of sciences in Cairo. So far the bulk of research work carried out in Egypt has been published in foreign journals or communicated to learned societies abroad. Although the Institut d'Egypte was founded in 1859 (reviving an older institute founded by Napoleon) and counts among its four sections one for Physical and Mathematical Sciences and another for Medicine, Agronomy and Natural History, its main tendency remained literary and artistic. Thus we find Osman Ghaleb Pasha (1845-1920), the biologist, publishing his work on the migrations of Filaria rytipleurites in the Comptes rendus of the Paris Academy in 1878. Previously Mahmoud El Falaki Pasha (1830-85), the astronomer and physicist, published his work on terrestrial magnetism in the Comptes rendus of the Paris Academy (1856) and the Mémoires couronés et mémoires des Savants étrangers of the Belgian Academy (1856).

With the establishment of the Fouad I University in Cairo in 1925 scientific research in Egypt received a strong impetus. Thus from the Faculty of Science alone more than five hundred papers have already appeared embodying the results of original researches in different fields of pure science. Of these, nearly 350 papers have appeared in scientific journals and proceedings of learned societies abroad (with more than two hundred papers in British journals). The rest, representing only about 30 per cent of the total, were either communicated to learned societies in Egypt or published as bulletins or special publications by the University of Cairo. Other Faculties, such as Medicine and Engineering, have contributed to the growth of pure science in addition to their work in the fields of applied science.

Mention should also be made of scientific and technical departments of the Egyptian Government, such as the technical departments of the Ministry of Agriculture, the Physical Department, etc. These publish their researches as a rule in the form of Government bulletins. The Helwan Observatory publishes special reports. Other noteworthy publications are the "Flora of Egypt" (Vol. 1, Pteridophyta, Gymnospermæ and Angiospermæ; Part 1, Monocotyledons: Typhaceæ-Gramineæ), the tables of Legendre associated functions (with fifty thousand entries) and the special publications of the Marine Biological Station at Hurgada, all of which have been published by the Faculty of Science of the Fouad I University. In addition to the Institut d'Egypte referred to above, the following learned societies, among others, issue publications :

(1) The Fouad I Entomological Society, founded in 1907 and given its charter in 1923 (Bulletins and Mémoires).

(2) The Royal Geographical Society of Egypt, founded in 1875, re-organised in 1917 (Bulletins and Mémoires).

(3) The Mathematical and Physical Society of Egypt, founded in 1936 (Proceedings).

(4) The Egyptian Royal Medical Association, founded in 1919 (Journal).

The establishment of the Egyptian Academy of Sciences is thus a natural step in the development of scientific activities in Egypt. Following upon a number of preliminary meetings, the Academy was formally instituted in 1945. The Council consists of ten members representing the different branches of science (three for mathematical, physical and astronomical sciences, one for chemistry, five for the biological sciences and one for geology). The first scientific meeting of the Academy was held in April 1945, and monthly meetings are held on the first Tuesday of every month excluding the period from June to September. The first publication of the Academy is in the press and will appear shortly.

Reference should be made to the Royal Prizes in Science which have graciously been founded by His Majesty King Farouk. These consist of four annual prizes each of value $£ \mathrm{E}$. 1,000 (about $£ 1,025$ ), to be awarded for the best contributions to the progress of science. The prizes are one for mathematical and physical sciences, one for biology, one for chemistry and one for geology. A committee, presided over by the Minister of Education, has been appointed to consider the conditions for awarding these prizes.

\section{GEOLOGY IN SCHOOLS}

$\mathrm{A}$ T a meeting on April 5, the Geologists' Association held a discussion on "Geology in Schools". The weight of opinion seemed to be that geology, at any rate up to the higher certificate stage, should usually be worked in as a side-line rather than included as such in a syllabus, but that much more should be done in this way than at present. The Association is peculiarly fitted to discuss such a proposition, since it includes in its membership many to whom the science remains a side-line or hobby. Among those who were present and spoke or had sent in written contributions were headmasters of schools, school teachers of both sexes, museum curators, university teachers and others with practical experience, while among members present were several who are still at school; one of these last has since sent in an account of the difficulties he encountered when seeking to take geology as a subject for the higher certificate examination: it forms a clear first-hand statement of the position, which needs to be remedied. 
It is the intention of the Council of the Association to condense the contributions, already numbering more than two dozen, into a comprehensive report to be circulated to educational authorities and be placed on sale to non-members.

\section{The Desirability}

Geology is, in a sense, a fundamental subject, but is in turn dependent on physics, chemistry, mathematics, zoology and botany; an acquaintance with it ensures a wide basis in general science, essential if future specialists in a narrow field are to be valuable members of the community. It is unrivalled, if wisely handled, as a training in observation; for example, one schoolmaster mentioned that he would only identify specimens found by pupils if a clear statement of the exact locality was forthcoming. Not everyone, nor even every science pupil, need learn much geology, but at present there is a widespread ignorance of the scope and potentiality of the subject. Actual instances were alluded to, where research chemists, called upon to deal with mineral substances, showed complete ignorance of the fact that a geologist could tell them not only what elements, but also what compounds were present. Civil engineers and architects have sometimes failed to recognize the need for a geologist's opinion, but there has recently been much improvement in this respect.

Pupils found to be decidedly dull in normal classroom subjects often show great keenness when introduced to elementary field geology, and develop an interest and ability which, when once aroused, can be applied also to form-work in this and other subjects. A very strong case can and will be put together from the contributions to the discussion for making instruction in geology available before a pupil leaves school.

\section{The Opportunity}

There are few subjects to which geology is not to some extent relevant; physical geography is obviously directly dependent on geology, but several members pointed out that it is undesirable to treat geology as a part of geography, which is better regarded as one of the humanities than as a science. It is more and more realized that geography in turn is a necessary background to history. 'The 'father of history', Herodotus, included in his work much geography and a by no means insignificant amount of geology. Classical pupils are taught that the battle of Salamis was won by the use of the new silver coins known as 'Athenian Owls'. Are they taught where the silver came from and how it was obtained? They can read it in Demosthenes, if the more intentionally scientific works of Strabo and Pliny are not sufficiently 'pure' in language. If we teach the influence of resources of coal and iron on modern history, should not something be said about those substances ? Elementary chemistry can be made much more attractive if specimens from mines or quarries are substituted for bottles from a shelf. One speaker said he had introduced geology through solid geometry and optics, teaching crystallography and petrology, and rather scorning the collecting of fossils from quarries near his school; his views met with little support. A woman-teacher mentioned that she had recently given young children a lesson which began on Psalm civ and ended in geology !

Advantage should be taken of the collecting instinct, which shows itself in almost every child at some time. A master at a public school in the north of England gave the most usual age for boys as twelve-and-a-half to fourteen; but the president said that he himself developed it at the age of five and had not yet outgrown it at sixty-one. Collecting fossils and minerals has nearly all the advantages and none of the dis. advantages of the other usual manifestations of the instinct : it affords admirable training in observation, both in recording the place and mode of occurrence in the field and in detecting specific differences indoors. The collecting of birds' eggs is wholly destructive; that of insects and plants undesirable if or when it reaches a stage where rarities are affected. Neatness and orderliness can be inculcated in arrang. ing a geological collection as easily as one of stamps.

A remarkable instance of what can be done even in a country elementary school was given by the first speaker, Dr. Vernon Wilson, at whose suggestion the discussion was held. When working in a quarry in Corallian limestone, he had laid out on the grass all the fossils he had found. Three small boys, aged about ten, came up and gave him correctly the Latin generic and specific names of all his specimens, and told him how the fauna there differed from that in a nearby quarry showing a slightly different facies. Incidentally, they could also name correctly the butterflies and moths they had collected. ' In Leeds he had known boys from a secondary school able to name the ornamental stones used on the front of public houses and other buildings in the street and to say whence they were brought. Such instances serve to show what can be done by an enthusiastic teacher. The raising of the compulsory school age by one year gives additional opportunity; but are there the teachers able to turn it to advantage ?

\section{The Means}

The first essential for an improvement in the teaching of geology is, of course, a sufficiency of teachers capable of giving elementary instruction and cognizant of the methods of pursuing geology at further stages and of the ultimate prospects as a career. Little or no indoor apparatus is necessary in primary schools, and not much in secondary schools. Prof. A. E. Trueman, president of the Geological Society, who has already taken the lead in much work on this subject, stressed the need for a really attractive and sound book on geology for young people; no one is better fitted to supply the need than himself.

Opportunity for outdoor work is essential, but must vary greatly with the type of school. The class already mentioned, that started on petrology and crystallography, was taken for a fortnight's holiday trip to the Isle of Arran : a primary school in the poorer parts of London is almost dependent on museum visits - not quite, since the roof and walls of the school and other buildings, the pavements and roads, the fuels for home, factory and transport afford many openings for attractive lessons on subjects of which every voter should have learnt something. One headmaster, with plenty of geological interest at hand, pointed out that he was bound to give to the local education authority a fortnight's notice of any lesson to be given outside the walls of his school; but no weather forecast is yet available a fortnight ahead. Here a simple reform is obviously necessary; a quota of time, varying, perhaps, with the type of school and the locality could be assigned with freedom of adaptation to the weather; a reasonable grant for expenses should be available. A visit to a quarry may afford many opportunities 
for instruction besides those directly geological. The measuring of a face, actually or assumed to be inaccessible, is practical geometry; the drawing of it involves perspective; there may be some plantecology for botanists and so on.

The assistance of local museums is essential and can be greatly developed. Dr. F. J. North, of the National Museum of Wales, sent a valuable account of his work in this way. A contribution also came from Mr. H. E. Dudley, of the Scunthorpe Museum ; a locality where almost every inhabitant is directly dependent on geology for employment has obvious advantages in this respect.

One of the speakers chosen by the Council, Dr. R. $O$. Jones, was formerly guide-lecturer at the Museum of Practical Geology. It is essential for London school-children that this Museum should be reopened at the earliest possible moment, and that the courses of instruction for teachers should be resumed. For schools everywhere it is important that geological maps should become obtainable with the minimum of delay.

C. N. BRomehead.

\section{TRANSPORT OF WATER AND SALTS THROUGH PLANT TISSUES}

\author{
By Prof. H. LUNDEGARDH \\ Institute of Plant Physiology, Uppsala
}

A CTIVE salt absorption is a fundamental char$A$ acteristic of the living cell. In tissues and whole organisms the active transport of salts from specialized absorption organs to other parts of the body is clearly a matter of fundamental importance. The cellular mechanism of active transport of water and salts is probably similar in plants and animals; but plants are in several respects more convenient objects for experimental investigation.

\section{Absorption of lons in the Surface of the Protoplasm}

From studies of the potential difference between a root system and the surrounding solution at varying hydrogen ion concentrations of the latter, it was concluded that ${ }^{1}$ the plasma membrane holds a comparatively strong high molecular acid (symbolized as $\mathrm{H}^{+} R_{a}-$ ), its $p K$ amounting to 1-2 and concentration to $10^{-3}-10^{-4} \mathrm{~N}$. Also weak bases are obviously present, but the acid dissociation dominates, resulting in a normally negative potential difference. The surface of the protoplasm thus behaves as a complex mono- or multi-layer, the dissociated components forming a sparse mosaic in a neutral ground substance. The strong acid is probably identical with nucleotides (adenylic acid ${ }^{2}$ ) which are given off in small quantities from living roots. The nature of the ground substance and of the base is unknown. Proteins are not exuded from roots, and phosphatides are probably not present in the plasma membrane.

In contact with a very diluted acid the large anions $R_{\alpha}$ - are combined with $\mathrm{H}$-ions. In contact with a solution of a neutral salt $M+A$ - the H-ions are exchanged for $M$-ions. The reaction $\mathrm{H} R+M A \rightleftarrows$ $M R+\mathrm{H} A$ approximately obeys the law of mass action ${ }^{3}$, but hydration of the ions and the adsorption coefficients influence the equilibrium. A similar exchange is to be assumed in respect of the anions of the medium. Owing to the negative potential differ. ence (in wheat roots normally amounting to c. $-60 \mathrm{mv}$.) the cations are positively adsorbed on the surface of the root, whereas the anions are negatively adsorbed, that is, are more diluted than in the medium (Donnan equilibrium).

\section{Accumulation and Transport of Cations}

Metallic cations in the medium are exchanged for other metallic cations in the root tissue, a process which implies a non-polar movement of ions ${ }^{4}$. It occurs also under anaerobic conditions. The general principles of exchange-power, well known from soil colloids, are valid for root tissue; but the complicated structure of the living membranes sometimes creates almost complete impermeability for special cations (for example, sodium). Cations are shown as moving from negative points in the surface to negative points in the bulk of the protoplasm, partly by a 'turning over' of large anions, partly along 'adsorption tracks', that is, ionized chain molecules (Fig. 2). It is to be supposed that mineral ions afterwards move much faster than would be possible by diffusion only. Metallic cations of course accumulate in each structural unit which develops a corresponding adsorption potential. But an accumulation of metallic cations as free salts postulates the simultanepus accumulation of free anions. So far as such ions are produced in metabolism, cations also accumulate in the cell sap independently of an active uptake of anions from the medium. Such anions are $\mathrm{HCO}_{3}$ and organic acids, for example, malic acid, which plays an important part in the regulation of the internal $p \mathrm{H}$ of cells. If malic acid disappears again in respiration a corresponding quantity of metallic cations (for example, $K^{+}$) are exuded from the tissue.

\section{Accumulation and Transport of Anions}

Accumulation of inorganic salts in a cell or a tissue is the result of metabolic processes. According to the theory of 'anion respiration' a special respiratory system meshes into the active uptake and transport of anions. The theory is based on respiration experiments with a large variety of single neutral salts in the medium ${ }^{8}$. In these experiments not only the absorbed quantities of anions and cations were determined but also the quantity of exchanged cations (anions are normally exchanged only to a very small degree). In plotting the absorption of anions against the respiration, expressed as carbon dioxide evolution, the values arrange themselves along a straight line, intersecting the abscissa at a certain distance from the origin (Fig. 1). The values for the cation absorption are more irregularly scattered. The theory implies the existence of two separate respiration processes in the plant cells, 'ground respiration', which is not directly related to the uptake of salts, and 'anion respiration', the intensity of which is related to the quantity of salts accumulated during a definite time.

Anion respiration being much more sensitive to hydrogen cyanide than ground respiration suggests the idea of the active iron in the cytochrome-cyto. chromeoxidase system in some way promoting the transport of anions.

The change of valency of the iron atoms in a series of hæmin molecules is thought to effect the transport of anions according to the following scheme (see also Fig. 2) :

$$
\left(\begin{array}{l}
\mathrm{Fe}^{+++} \\
3 A^{-}
\end{array}\right) \underset{-\varepsilon}{\stackrel{+\varepsilon}{\rightleftarrows}}\left(\begin{array}{l}
\mathrm{Fe}^{++} \\
2 A^{-}
\end{array}\right)+A^{-} .
$$

